Temizkan, M. (2014) Ortaokul Türkçe ders kitaplarının Türkçe dersi öğretim programındaki temel beceriler açısından incelenmesi. Ana Dili Eğitimi Dergisi, 2(1), 49-72.

Ana Dili Eğitimi Dergisi
Journal of MotherTongueEducation
ADED - JOMTE
www.anadiliegitimi.com

\title{
Ortaokul Türkçe Ders Kitaplarının Türkçe Dersi Öğretim Programındaki Temel Beceriler Açısından İncelenmesi
}

Mehmet Temizkan ${ }^{1}$

\begin{abstract}
Özet
Bu araştırmanın amacı ortaokul Türkçe ders kitaplarının 2005 Türkçe Dersi Öğretim Programı'nda yer alan temel beceriler açısından bir değerlendirmesini yapmaktır. Araştırma genel tarama modelinde betimsel bir çalışmadır. Araştırmanın evreni Hatay ili merkezindeki ortaokullarda okutulmakta olan 5. 6. 7. ve 8. sınıf Türkçe kitaplarıdır. Araştırmada veri toplamak amacıyla 2005 Türkçe Dersi Öğretim Programı́ndaki Temel Beceriler ve Alt Beceriler ölçeği kullanılmıştır. Bu ölçek 2005 Türkçe Dersi Öğretim Programı'nın “Temel Beceriler” başlığı altındaki becerilerden ve bu becerilere ilişkin literatür taraması yoluyla tespit edilen alt becerilerden oluşmaktadır. Çalışmada verilerin analiz edilmesi amacıyla nitel veri analizi tekniklerinden doküman incelemesine başvurulmuştur. Sonuç olarak Türkçe ders kitaplarının temel beceriler açııından istenen düzeyde olmadıkları tespit edilmiştir.
\end{abstract}

Anahtar Kelimeler: Temel beceriler, Türkçe ders kitapları, Türkçe dersi programı.

\section{Investigation of Secondary Turkish Course Books in Terms of Basic Skills in Turkish Course Curriculum}

\begin{abstract}
The aim of this research is to evaluate secondary Turkish coursebooks in terms of basic skills in 2005 Turkish Course Curriculum. The model applied in the study is descriptive method. The sample of this study consists of 5th, 6th, 7th and 8th grade Turkish coursebooks used in secondary schools of Hatay city centre. Basic Skills and Sub- Skills Scale of 2005 Turkish Course Curriculum was used in order to collect data in the research. This scale was consisted of sub-skills determined through literature review related to items under the title of "Basic Skills" of 2005 Turkish Course Curriculum. Amongst qualitative data analysis techniques, document review was applied with the aim of analysing data in the study. As a result, it was determined that Turkish coursebooks were not desired level in terms of basic skills.
\end{abstract}

Key Words: Basic skills, Turkish coursebooks, Turkish course curriculum.

\footnotetext{
${ }^{1}$ Doç. Dr. Mustafa Kemal Üniversitesi Eğitim Fakültesi Türkçe Eğitimi Bölümü, Hatay. E-posta: temizkan.mehmet@hotmail.com
} 


\section{Giriş}

Bireyin çok hızlı bir şekilde değişen çevre koşullarına uyum sağlayabilmesinin en önemli şartlarından ikisi bilgi edinme ve beceri geliştirmedir. Sosyal, kültürel, teknoloji, bilişim vb. alanlarda kendini gerekli bilgi ve becerilerle donatmış kişiler, çevreye uyum sağlama ve üretkenlik konularında önemli bir adım atmış olurlar. Bu nedenle birey, bilginin önemi, gerekliliği, bilgiyi elde etme yolları, bilginin kullanımı gibi alanlarda bir farkındalık oluşturmalıdır.

Bilgi, Türkçe Sözlük'te (1996) “İnsan aklının erebileceği olgu, gerçek ve ilkelerin bütünü; öğrenme, araştırma veya gözlem yolu ile elde edilen gerçek; insan zekâsının çalışması sonucu ortaya çıkan düşünce ürünü; zihnin kavradığı temel düşünce." şeklinde tanımlanmaktadır. Bu tanım incelendiğinde bilgi kavramının genel olarak akıl, zekâ, araştırma, gözlem, öğrenme, düşünme ve düşünce kavramlarıyla yakın bir ilişki içinde olduğu görülmektedir. Buna göre bilginin elde edilmesi, bir süreci gerektirmektedir. Bu süreç insan aklının araştırma, gözlem gibi yöntemleri kullanarak olaylar, durumlar, kavramlar, kişiler vb. üzerinde düşünmesi ve bu düşünme sonucunda bazı düşüncelere ulaşmasını gerektirmektedir. Sağlıklı bir şekilde işleyen bu sürecin sonunda elde edilen düşünce ürünleri, bilgiyi oluşturmaktadır.

Günümüzde bilgiyi elde etme yollarını bilme ve bilgiye ulaşma kadar önemli bir diğer nokta, ulaşılan bilgilerin kullanımıdır. Buna göre farklı disiplinlerin iç içe geçmesiyle birlikte yaşanan bilgi çeşitliliği karşısında bireyin ne kadar çok bilgiye sahip olduğu değil, bu bilgileri nasıl kullandığı daha fazla önem kazanmaktadır. Bu noktada bireyin öncelikle kendine sorması ve cevaplarını bulması gereken bazı sorular vardır. Örneğin "Her bilgiyi her ortamda kullanabilir miyim?, Sahip olduğum birçok bilgiden en etkili olanına nasıl karar verebilirim?, Sahip olduğum bilgilerle yeni bilgilere ulaşmak mümkün müdür?" gibi sorular bunlardandır. Bu sorular ve bunlara verilecek cevaplar bilgi kavramı üzerinde temel bir değişimin dönüm noktasını oluşturmaktadır. Bu nokta, bilginin ulaşılmak istenen amaç değil, kullanmak üzere edinilen bir araç olmasında yatar. Günümüzde bilgiye yönelik değişen bakış açısı; bilginin olguları, kavramları, ilkeleri ve süreçleri ezberlemenin değil, bilgiyi etkili bir araç olarak kullanmanın daha önemli olduğu noktasında düğümlenmektedir. Buna göre birey bilginin, problem çözme sürecinde, eleştirel ve yaratıcı düşünmede, sağlıklı ve düzenli iletişim kurmada etkili bir şekilde nasıl kullanılması gerektiğini öğrenmelidir. Bilginin bu şekilde kullanımı, bazı temel becerilere sahip olmayı gerektirir. Bu nedenle üzerinde durulması gereken başka bir kavram da "beceri" kavramıdır. 
Beceri Kavramı ve 2005 Türkçe Dersi (6-8. Sınıflar) Öğretim Programı’nda Yer Alan Temel Beceriler

Ustalık, maharet gibi kelimelerle de ifade edilen beceri kavramı, kişinin bir işi başarma ve bir işlemi amaca uygun olarak sonuçlandırma yeteneği, bir kimsenin bedensel ya da düşünsel bir çaba göstererek bir işi kolaylık ve ustalıkla yapabilmesi gibi anlamlara gelmektedir. Buradaki ifadelere bakılırsa beceri ile ilgili olarak bazı çıkarımlarda bulunmak mümkündür. Bunlardan birisi, becerinin bir işi başarıyla sonuçlandırabilmek için edinilmiş olması gerekliliğidir. Bir diğeri de edinilmiş olan bu beceriler yardımıyla herhangi bir işlemi gerçekleştirme, bir işi yerine getirme yani uygulama durumudur. O halde becerilerin günlük hayatta uygulamaya dönük bir tarafı vardır. Kişi, ilgisini, yeteneğini, bilgi birikimini ne kadar uygulamaya döker, bunlar yardımıyla ne kadar iş başarabilirse o kadar becerikli sayılabilir.

Yukarıdaki genel ifadelerden sonra beceri kavramının eğitim boyutuna bakılırsa, burada da uygulamanın ön plana çıktığı görülür. Eğitim öğretim ortamında beceri, öğrenme süreci içerisinde kazanılması, geliştirilmesi ve yaşama aktarılması tasarlanan kabiliyetler olarak tanımlanmaktadır MEB, 2005). Buna göre beceri hem bilgi gerektiren hem de performans içeren bir kavramdır. Çünkü bir işlemi başarıyla sonuçlandırmak, bir işi yerine getirmek bir yönüyle gerekli bilgilere sahip olmayı; diğer yönüyle de bu bilgileri uygulamaya geçirmeyi zorunlu kılmaktadır.

Beceri kavramı Illköğretim Türkçe Dersi Öğretim Programı ve Kılavuzu (6. 7. 8. sınıflar)'nda ele alınan önemli başlıklardan birisidir. Temel beceriler başlığı altında Türkçeyi doğru, güzel ve etkili kullanma, eleştirel düşünme, yaratıcı düşünme, iletişim kurma, problem çözme, araştırma, karar verme, bilgi teknolojilerini kullanma, girişimcilik gibi maddelere yer verilmektedir. Burada isimleri yer alan bu temel beceriler öğrencilerin dil becerilerindeki gelişimleriyle bağlantılı, yatay olarak bir yılın sonunda, dikey olarak da sekizinci sınıfın sonunda kazanacakları ve hayat boyu kullanacakları temel beceriler olarak algılanmaktadır (2005: 5). Buna göre okullarımızda yaptırılan Türkçe öğretimi öğrencileri, anlama ve anlatma boyutunda geliştirdiği gibi günlük hayatta karşılaştıkları problemlerin çözümünde, eleştirel düşünmede, yaratıcılık becerilerinin gelişiminde, bilgi teknolojilerini tanıma ve kullanmalarında, karar verme süreçlerinde vb. onlara gerekli bilgi ve donanımı sağlayacaktır. Aşağıda TDÖP'te yer alan temel becerilerle ilgili kısa açıklamalar yer almaktadır.

Eleştirel Düşünme: Düşünmek farklı bulgular, olaylar, durumlar arasında sınıflama, analiz, sentez, çıkarım, karşılaştırma gibi zihinsel faaliyetlerin uygulanmasıyla yeni bulgulara ulaşma süreci olarak tanımlanabilir. Düşünme becerilerine sahip olan bireyler, bilgiyi ne amaçla edindiklerini, nasıl kullanacaklarını ve bilgiye nasıl ulaşacaklarını bilerek hareket ederler; bu durum düşünmeyi öğrenmeyi ve anlamlı öğrenmeyi de beraberinde getirir (Köken, 2004: 127). Bununla birlikte her durum, olay vb. karşısında aynı düşünme süreçlerinin işletilmesi gibi bir zorunluluk yoktur. Buradan 
hareketle eleştirel düşünme, yaratıcı düşünme, analitik düşünme, yakınsak düşünme, ıraksak düşünme gibi birbirinden farklı düşünme süreçleri geliştirilmiştir. Bunların içinde en önemlilerinden birisi eleştirel düşünmedir.

Eleştirel düşünme bireyin elde ettiği bilgiyi sürekli sorgulayarak, standartlara ve ölçütlere göre değerlendirme ve bir yargıya varmasını sağlayan beceridir (Semerci, 1999b: 12). Gültekin'e (2004: 42) göre eleştirel düşünme, herhangi bir durum, sav veya olayın doğruluğunu, yanlışlığını değerlendirme ve karar verme sürecidir. Burada dikkat edilmesi gereken nokta eleştirinin amacının mutlaka karşı çıkmak değil, gerçeği açığa çıkarmak, anlamak olduğudur. Eleştirel düşünme, bir sorunu açığa çıkarmak, o sorunun özüne inerek hem olumlu hem de olumsuz yanlarını aydınlatma demektir (Ipşiroğlu, 1992: 9). Yapılan literatür çalışmasından sonra olay, durum ve konulara sorgulayıcı gözle bakma, sebep-sonuç ilişkilerini bulma, benzerlik ve farklılıkları yakalama, çıkarımlarda bulunma, öğrendikleri arasında karşılaştırmalar yapma, okurken, dinlerken vb. zihninde sorular oluşturma ve cevaplar bulma, edindiği bilgileri sınıflandırma, sebep-sonuç ilişkilerini bulma, ayrıntılarda benzerlik ve farklııkları yakalama, çeşitli ölçütleri kullanarak sıralama yapma, verilen bilgilerin kabul edilebilirliğini, geçerliliğini belirleme, analiz etme, değerlendirme, anlamlandırma, çıkarımda bulunma gibi alt becerilerden oluşmaktadır.

Yaratıcı Düşünme: Yaratıcılık hemen her bireyde var olan, çevre koşulları ve aile ortamı ile aile içi iletişim ve etkileşim, eğitim ortamları gibi birçok değişken tarafından etkilenen bir beceridir. Bundan dolayı doğuştan itibaren her bireyde bulunan yaratıcılık yeteneğinin eğitim yoluyla geliştirilmesi mümkündür. San (1979: 177) yaratıcılığı, tüm duygusal ve zihinsel etkinliklerde, her türlü çalışma ve uğraşın içinde var olan, insan yaşamının ve gelişiminin tüm yönlerinin temelini meydana getiren bir yeti olarak tanımlamaktadır. Yaratıcılık; bilinci yoğunlaşmış insanın kendi dünyasıyla karşılaşması (May, 1994: 74); problemlerin hissedilmesi, düşüncelerin oluşturulması, geliştirilmesi ve verilerin iletilmesi süreci (Torrance, 1995: 23); bireyin var olan kalıplardan kurtulması, anayoldan ayrılması ve farklı olmaktan korkmaması (Saban, 2000: 87) anlamına gelmektedir. Yaratıcılıkta özgünlük, olağanüstülük, kural dışılık, değişik olma (sıra dışılık), bilinenlerin dışında kullanma, şimdiye değin olduğundan başka biçimde birleştirme gibi özellikler bulunur. Yaratıcılık kavramı, yaratıcı düşünmeyi de beraberinde getirmektedir. Yaratıcı düşünme becerisi; öğrencilerin bir temel fikri ve ürünü değiştirme, birleştirme yeniden farklı ortamlarda kullanma ya da tamamen kendi düşüncelerinden yola çıkarak yeni ve farklı ürünler ve bilgiler üretme, olaylara farklı bakabilme, küçük çaplı da olsa bazı buluşlar yapabilmeyi kapsar. Bu araştırmada yaratıcı düşüncenin alt boyutları yeni, farklı bilgiler ve ürünler ortaya koyma, olaylara farklı bakış açısıyla bakabilme, sorunlara kendine özgü çözümler bulabilme, konu veya durumla ilgili çok sayıda düşünce üretme, bir kavramı kendime göre tanımlayıp yorumlama, hayal gücünü kullanma gibi alt boyutlarıyla ele alınmaktadır. 
Araştırma-Sorgulama Becerisi: Araştırma becerisi; doğru ve anlamlı sorular sorarak problemi fark etme ve kavrama, problemi çözmek amacıyla neyi ve nasıl yapması ile ilgili araştırma planlaması yapma, sonuçları tahmin etme, çıkabilecek sorunları göz önüne alma, sonucu test etme ve fikirleri geliştirmeyi kapsar. Anlamlı tahminde bulunma, uygun araştırma ortamına karar verme, araştırmada ne tip ve ne kadar delil toplaması gerektiğine karar verme, bilimsel yaklaşımı kullanarak araştırmayı planlama, nasıl gözlem ve kıyas yapacağını belirleme, araç gereç kullanma, doğru ve hassas ölçümler yapabilme, sonuçları sunma yollarını belirleme, sonuçların tekrar incelenmesi gerekip gerekmediğine karar verme, bulunanlarla asıl fikrin bağlantısını kurma, bulunanları uygun bir dille ifade etme, verileri ortaya koyma, sonucu destekleyici verilerin yeterliliğine karar verme, bulunanların ilk beklentileri karşılayıp karşılamadığına karar verme gibi alt becerileri içerir.

Problem Çözme Becerisi: Başka bir deyişle problem çözme becerisi, bireyin geçmiş yaşantılarından şimdiki zamana dek günlük yaşamda karşılaştığı problemlerle başa çıkma amacıyla kullandığı çözüme yönelik eylemlerinin birikiminden ve bu yaşantıları algılama biçiminden oluşmaktadır (Ittenbach ve Harrison, 1990, akt. Sardoğan ve Kaygusuz, 2006: 81). Problem çözme becerisi önemli bir sosyal beceri ve kişilik özelliği olarak bireyin sosyal uyumunu ve günlük yaşama yönelik başarısını yakından etkilemektedir. Problem çözme becerisi; öğrencinin yaşamında karşısına çıkacak problemleri çözmek için gerekli olan beceriyi kapsar. Alt becerileri ise problemin anlaşııması, gerekirse alt basamakların ya da problemin köklerinin bulunması, problemi uygun şekilde çözmek için planlama yapma, işlemler sırasında çalışmaların gözlenmesi, gerektiğinde stratejilerin ve planların değiştirilmesi, yöntemlerin sınanması, çözüm aşamasında elde edilen veri ve bilgilerin değerlendirilmesi, çözüme ulaşılınca çözümün anlamlılığının ve işe yararlılığının değerlendirilmesini ve yeni problemleri fark etmesini içerir.

İletişim Kurma Becerisi: İletişim becerisi; konuşma, dinleme, okuma, yazma gibi sözel ve vücut dili işaret dili gibi sözel olmayan iletişim becerilerini etkili ve bulunduğu ortama uygun olarak kullanmayı kapsar. Bulunduğu ortama uygun olarak kullanması gereken konuşma üslûbunu belirleme, uygun şekilde hitap etme, vücut dilini gerektiği yerde gerektiği ölçüde kullanma, aktif olarak dinleme, söz hakkı verme, grup içerisinde etkin bir şekilde arkadaşlarıyla etkileşim içerisinde olma, okurken etkin ve hızlı bir şekilde okuma, okuduğunu anlama ve eleştirme, yazarken ve konuşurken hedef kitleye uygun üslûp kullanma, kendi ve başkalarının yazdıklarını eleştirme gibi alt becerileri içerir.

Bilgi Teknolojilerini Kullanma Becerisi: Teknoloji, insanların mevcut araç ve gereçleri kullanarak hayatlarını kolaylaştıracak yeni ürünler elde etmesidir. İnsanların daha çağdaş bir ortamda yaşama beklentisi teknolojideki hızlı gelişmeyi de beraberinde getirmiştir. Çağımızda bilim ve teknolojide meydana gelen hızlı değişim ve gelişmeler iletişim ve bilgi teknolojilerini de önemli ölçüde etkilemekte, hızla yayılmakta olan yenilikler yaşamın tüm boyutlarında hissedilmektedir. Bu değişim ve gelişme bilginin üretilmesini, yayılmasını, paylaşılmasını ve kullanılmasını hızlandırmış, bilgi, 
eğitimde olduğu kadar, toplum yaşamında, kamu hizmetlerinde ve ekonomide de en temel öğesi haline gelmiştir. Bilgi teknolojilerini kullanma becerisi; bilginin araştırılması, bulunması, işlenmesi, sunulması ve değerlendirilmesinde teknolojiyi kullanabilme becerilerini kapsar. Bilgi teknolojilerini yerinde kullanma, kullanılacak bilgi teknolojisine karar verme; bilgi teknolojilerini kullanırken planlama yapma; bilgi teknolojilerinin kullanılması için gerekli becerilere sahip olma; bilgi teknolojilerini kullanarak elde ettiği bilgilerden yeni bilgiler üretme; bilgi teknolojileri aracılığıyla bilgi alışverişinde bulunma; birden fazla bilgi teknolojisini kullanma; teknolojiyi amacına uygun olarak kullanma; teknolojiye karşı olumlu tutum geliştirme; bilgi teknolojileri kullanarak karar verme alt becerilerini içerir.

Karar Verme Becerisi: Karar verme, olaylara ilişkin olasılık hesapları yaparak iki veya daha fazla seçenek arasından bir seçim yapma yetisi, süreci veya bu amaçla kullanılan yöntem şeklinde tanımlanabilir (Budak, 2000). Karar verme davranışı, karar verilmesi gereken bir durumun farkına varılması ile başlayan ve bireyin bu durum karşısında ne zaman ve nasıl karar vereceğini belirlemesi ile sonlanan bir etkinliktir. Birey, karar verme süreci içerisinde belirli bir yaklaşımda bulunarak durumu değerlendirmekte, seçenekleri ve bu seçeneklerin sonuçlarını incelemekte ve değerlendirmenin sonucu olarak istediği seçime yönelmektedir (Carroll, 1980. akt: Ersever, 1996). Karar verme becerisi, bağımsız olarak karar verme sorumluluğu üstlenme; olası seçenekler üretme ve bunlar hakkında bilgi toplama; seçeneklerin olumlu ve olumsuz yönleri hakkında bilgi toplama; karar vermede başkalarının duygu ve düşüncelerini de dikkate alma; seçenekleri karşılaştırma; seçeneklerden birine karar verme; seçenekleri gözden geçirme; seçeneklerin olumlu ya da olumsuz yanlarını tam olarak bilmemesine karşın seçimde bulunma gibi alt becerileri içermektedir.

Girişimcilik Becerisi: Çalışmada yer verilen bir diğer beceri girişimcilik becerisidir. Girişimcilik; sosyal ilişkilerde, iletişimde, iş dünyasında ve benzeri alanlarda gerekli ve etkili davranışları uygun bir şekilde ve uygun zamanda ortaya koymak veya talep görebilecek bir ürünü veya hizmeti daha iyi üretebilmek ya da pazarlayabilmek amacıyla yeni bir sistem kurmak için gerekli olan becerilerdir. Girişimcilik becerisi; insan ilişkilerinde uyumlu davranışlar gösterme; görev ve sorumluluklarını planlama; risk alma; planlarını uygulama ve amacına ulaşmak için harekete geçme; grupla ya da tek başına çeşitli sosyo-kültürel etkinlikler düzenleyebilme (oyunlar, piknik, yarışma vb.); ikna edebilme ve kendine güvenebilme gibi alt becerileri içerir.

Girişimci tutum, kişinin içinde bulunduğu koşullara aldırmaksızın, davranışlarını, kendi istediği amaçları gerçekleştirmek yönünde kullanabilmesidir. Bu anlayışa göre birey çevresel koşulların ve onların uyardığı duygu ve heyecanların önüne geçerek; inandığı ilkeleri davranışlarına aktarabilir. Girişimcilik becerileri yüksek olan bireyler karşılaştıkları problemleri girişimci yetenekleri ile çözümlemeye çalışırlar. Çünkü girişimci birey geçici duygu, heyecan ve çevre koşullarına dayanarak karar vermez. Girişimci bireyin en belirgin özelliği, inandığı değerleri vereceği kararların temeline 
almasıdır. Dolayısıyla girişimci bireyin davranışlarının temelinde bilinçli kararları, bilinçli kararların temelinde de inandıkları temel değerler bulunmaktadır (Cüceloğlu, 2001: 169-170).

Bu açıklamalarda sonra araştırmanın problem cümlesi "2005 Türkçe Dersi Öğretim Programı'nda yer verilen temel beceriler, ortaokul Türkçe ders kitaplarındaki metinlerde hangi oranda kullanılmaktadır?" şeklinde oluşturulmuştur.

\section{Yöntem}

Bu bölümde araştırmanın modeli, amaç, alt amaçlar, evren ve örneklem, sınırlııklar gibi başlıklar altında bilgi verilmiştir.

\section{Araştırmanın Modeli}

Bu araştırma genel tarama modelindedir. Tarama modelleri, geçmişte ya da halen var olan bir durumu var olduğu şekliyle betimlemeyi amaçlayan araştırma modelleridir. Tarama modelleri iki şekilde sınıflandırılabilir. Bunlar, genel tarama modelleri ile örnek olay taramalarıdır. Genel tarama modelleri, çok sayıda elemandan oluşan evren hakkında genel bir yargıya varmak amacı ile evrenin tümü ya da ondan alınan bir grup, örnek ya da örneklem üzerinde yapılan tarama modelidir (Karasar, 2009: 77-79). Bu araştırmada evren içinden bir örneklem alınarak ortaokul Türkçe ders kitaplarının temel beceriler açısından bir değerlendirmesi yapılmaya çalışılmıştır.

\section{Araştırmanın Amacı}

Araştırmanın amacı ortaokul Türkçe ders kitaplarının TDÖP'te yer alan temel beceriler açısından değerlendirmesini yapmaktır. Bu amaç doğrultusunda aşağıdaki alt amaçlara ulaşılmaya çalışılımıştır:

\section{Alt Amaçlar}

2005 Illköğretim Türkçe Dersi Öğretim Programı ve Kılavuzu (6, 7. 8. Sınıflar)'nda yer alan temel becerilerden eleştirel düşünme becerisinin öğrencilere kazandırılmasını sağlayacak ifadelere ortaokul Türkçe ders kitaplarında ne oranda yer verildiğini tespit etmek.

2005 TDÖP'te yer alan temel becerilerden yaratıcı düşünme becerisinin öğrencilere kazandırımasını sağlayacak ifadelere ortaokul Türkçe ders kitaplarında ne oranda yer verildiğini tespit etmek.

2005 TDÖP'te yer alan temel becerilerden problem çözme becerisinin öğrencilere kazandırılmasını sağlayacak ifadelere ortaokul Türkçe ders kitaplarında ne oranda yer verildiğini tespit etmek.

2005 TDÖP'te yer alan temel becerilerden iletişim kurma becerisinin öğrencilere kazandırılmasını sağlayacak ifadelere ortaokul Türkçe ders kitaplarında ne oranda yer verildiğini tespit etmek.

2005 TDÖP'te yer alan temel becerilerden girişimcilik becerisinin öğrencilere kazandırılmasını sağlayacak ifadelere ortaokul Türkçe ders kitaplarında ne oranda yer verildiğini tespit etmek. 
2005 TDÖP'te yer alan temel becerilerden karar verme becerisinin öğrencilere kazandırılmasını sağlayacak ifadelere ortaokul Türkçe ders kitaplarında ne oranda yer verildiğini tespit etmek.

2005 TDÖP'te yer alan temel becerilerden araştırma-sorgulama becerisinin öğrencilere kazandırılmasını sağlayacak ifadelere ortaokul Türkçe ders kitaplarında ne oranda yer verildiğini tespit etmek.

2005 TDÖP'te yer alan temel becerilerden bilgi teknolojilerini kullanma becerisinin öğrencilere kazandırılmasını sağlayacak ifadelere ortaokul Türkçe ders kitaplarında ne oranda yer verildiğini tespit etmek.

\section{Evren ve Örneklem}

Araştırmanın evrenini 2012 - 2013 eğitim-öğretim yılında Hatay il merkezindeki ortaokullarda okutulmakta olan 5. Sınıf Ada Yayınları Türkçe Ders Kitabı, 6. Sınıf Doku Yayınları Türkçe Ders Kitabı, 7. Sınıf Koza Yayınları Türkçe Ders Kitabı ve 8. Sınıf Enderun Yayınları Türkçe Ders Kitabı oluşturmaktadır.

\section{Sınırlılıklar}

1. Araştırmada TDÖP'te bulunan temel beceriler üzerinde çalışılmıştır. Bu becerilerden Türkçeyi doğru, düzgün ve etkili kullanma becerisine yer verilmemiştir. Bunun nedeni bu maddenin başlı başına ayrı bir çalışmanın konusu olabilecek bir nitelik taşıması ve metin türlerine göre bazı değişkenler içermesidir.

2. Araştırma, Türkçe ders kitaplarında yer alan okuma metinleri ile sınırlandırılmıştır.

\section{Veri Toplama Araçları}

Araştırmada veri toplama aracı olarak "Türkçe Dersi Öğretim Programında Yer Alan Temel ve Alt Beceriler Ölçeği” kullanılmıştır (Ek 1). Geliştirilen ölçekte 2005 Türkçe Dersi Öğretim Programı́nda yer alan 9 temel beceri ve bu temel becerilere ilişkin alt beceriler yer almaktadır. Ölçekte yer alan temel becerilere ilişkin "alt beceriler" alanyazın taraması yapılarak ulaşılan bulgulardan hareketle araştırmacı tarafından geliştirilmiştir.

\section{Verilerin Analizi}

Çalışmada verilerin analiz edilmesi amacıyla nitel veri analizi tekniklerinden doküman incelemesine başvurulmuştur. Doküman incelemesi, araştırılması hedeflenen olgu veya olgular hakkında bilgi içeren yazılı materyallerin analizini kapsar. Dokümanlar, nitel araştırmalarda etkili bir şekilde kullanılması gereken önemli bilgi kaynaklarıdır. Bu tür araştırmalarda, araştırmacı, ihtiyacı olan veriyi, gözlem veya görüşme yapmaya gerek kalmadan elde edebilir. Bu çalışmada öncelikle 
araştırmanın amacına uygun olarak belirlenen dokümana ulaşılmış ve okunup incelenerek belirlenen ölçütler çerçevesinde fişlemeler yapılmıştır. Daha sonra elde edilen veriler analiz edilerek bulgular bölümünde sunulmuştur.

\section{Bulgular}

\section{Ortaokul Türkçe Ders Kitaplarındaki Metinlerde Eleştirel Düşünmeye İlişkin Bulgular}

Ortaokul Türkçe Ders Kitaplarındaki metinlerde temel becerilerden eleştirel düşünmeye ilişkin bulgular aşağıdaki tabloda verilmiştir.

Tablo 1. Ortaokul Türkçe Ders Kitaplarında Temel Becerilerden Eleştirel Düşünmeye İlişkin Bulgular

\begin{tabular}{|l|c|c|c|c|}
\hline \multicolumn{1}{|c|}{ Alt Beceriler } & 5. Sınıf & 6. Sınıf & 7. Sınıf & 8. Sınıf \\
\cline { 2 - 5 } & $\mathrm{f}$ & $\mathrm{f}$ & $\mathrm{f}$ & $\mathrm{f}$ \\
\hline olay, durum ve konulara sorgulayıcı gözle bakma & 6 & 19 & 1 & 4 \\
\hline sebep-sonuç ilişkilerini bulma & 3 & 4 & 1 & 0 \\
\hline benzerlik ve farklılıkları yakalama & 1 & 4 & 1 & 3 \\
\hline çıkarımlarda bulunma & 8 & 11 & 4 & 4 \\
\hline öğrendikleri arasında karşılaştırmalar yapma & 2 & 4 & 1 & 2 \\
\hline okurken, dinlerken vb. zihninde sorular oluşturma & 0 & 0 & 0 & 0 \\
\hline edindiği bilgileri sınıflandırma & 0 & 0 & 0 & 0 \\
\hline Toplam & 20 & 42 & 8 & 13 \\
\hline
\end{tabular}

Tablo 1'e göre Türkçe Dersi Öğretim Programı'nda belirtilen temel becerilerden eleştirel düşünme, ortaokul ders kitaplarındaki metinlerde düzenli bir dağılım göstermemektedir. Toplam değerlere bakıldığında 5. Sınıf Türkçe ders kitabında $(f=20) ; 6$. Sınıf Türkçe ders kitabında $(f=42) ; 7$. Sınıf Türkçe ders kitabında $(f=8) ; 8$. Sınıf Türkçe ders kitabında $(f=13)$ noktada eleştirel düşünmeye yönelik ifadeler bulunduğu görülmektedir.

Eleştirel düşünme, ders kitapları arasında olduğu gibi alt başlıklar açısından da düzensiz bir dağılım göstermektedir. Buna göre 5. sınıftan 8. sınıfa doğru olay, durum ve konulara sorgulayıcı gözle bakma $(f=6 ; f=19 ; f=1 ; f=4)$; sebep-sonuç ilişkilerini bulma $(f=3 ; f=4 ; f=1 ; f=0)$; benzerlik ve farklııkları yakalama $(f=1 ; f=4 ; f=1 ; f=3)$; çıkarımlarda bulunma $(f=8 ; f=11 ; f=4 ; f=4)$; öğrendikleri arasında karşılaştırmalar yapma $(f=\quad 2 ; f=4 ; f=1 ; f=2)$ şeklinde yer almaktadır. Eleştirel düşünmenin alt başlıklarından "okurken, dinlerken zihninde sorular oluşturma" ve "edindiği bilgileri sınıflandırma" alt başlıklarına ilişkin ders kitaplarında herhangi bir ifadeye rastlanmamıştır.

\section{Eleştirel Düşünmeye Yönelik Türkçe Ders Kitaplarından Örnekler}

Örnek 1. Çevrenizdeki birilerinin zeki olduğundan söz edildiğini duymuşsunuzdur. Peki, onlara neden böyle denir? Güzel mi konuşurlar? Yaptıkları resimler çok mu beğenilir ya da piyano, gitar mı çalarlar? Matematik sorularını en hızlı onlar mı yaparlar? (5. sınıf) 
Alt Başlık: Olay, durum ve konulara sorgulayıcı gözle bakma.

Örnek 2. Bu sokağı öteki sokaklardan ayıran en güzel yanı, ağaçların ve yeşilliğin bol olmasıdır. (5. sınıf)

Alt Başlık: Benzerlik ve farklııkları yakalama.

Örnek 3. Dört arkadaş yemeklerini hep beraber yermiş. Sofraya oturduklarında içlerinden birinin olmadığını fark etmişler. Çünkü sofrada ceylanın her zaman oturduğu yer boşmuş. (6. sınıf)

Alt Başlık: Çıkarımda bulunma.

Örnek 4. Küreselleşme, başka ulusların yemeklerini tanımamızı sağlarken ne yazık ki kendi mutfaklarımızı unutmamıza neden oluyor. (6. sınıf)

Alt Başlık: Sebep-sonuç ilişkilerini bulma.

Örnek 5. Az önce saydıklarımız, sinemanın yarattığı düsssel kahramanlardı. Çoğu, teknolojinin de üstün gücüyle inanılmaz serüvenler yaşıyor. Ama ben size düşsel bir kahramandan değil gerçek bir insandan söz ediyorum. Sizin, benim gibi bir insan. (6. sınıf)

Alt Başlık: Karşılaştırmalar yapma.

\section{Ortaokul Türkçe Ders Kitaplarındaki Metinlerde Yaratıcı Düşünmeye İlişkin Bulgular}

Ortaokul Türkçe Ders Kitaplarındaki metinlerde temel becerilerden yaratıcı düşünmeye ilişkin bulgular aşağıdaki tabloda verilmiştir.

Tablo 2. Ortaokul Türkçe Ders Kitaplarında Temel Becerilerden Yaratıcı Düşünmeye lilişin Bulgular

\begin{tabular}{|l|c|c|c|c|}
\hline \multicolumn{1}{|c|}{ Alt Beceriler } & 5. Sınıf & 6. Sınıf & 7. Sınıf & 8. Sınıf \\
\cline { 2 - 5 } & $\mathrm{f}$ & $\mathrm{f}$ & $\mathrm{f}$ & $\mathrm{f}$ \\
\hline yeni, farklı bilgiler ve ürünler ortaya koyma & 0 & 0 & 0 & 0 \\
\hline olaylara farklı bakış açısıyla bakabilme & 0 & 3 & 2 & 3 \\
\hline sorunlara kendine özgü çözümler bulabilme & 0 & 0 & 0 & 0 \\
\hline konu veya durumla ilgili çok sayıda düşünce üretme & 0 & 0 & 0 & 1 \\
\hline hayal gücünü kullanma & 0 & 1 & 0 & 2 \\
\hline bir kavramı kendime göre tanımlayıp yorumlama & 0 & 0 & 0 & 0 \\
\hline Toplam & 0 & 4 & 2 & 6 \\
\hline
\end{tabular}

Tablo 2'de Türkçe Dersi Öğretim Programı'nda belirtilen temel becerilerden yaratıcı düşünmenin ortaokul ders kitaplarındaki dağılımı verilmektedir. Toplam değerlere bakıldığında 5 . sınıf Türkçe ders kitabında yaratıcı düşünmeye ilişkin herhangi bir ifadeye rastlanmamaktadır. Buna karşın 6. Sınıf Türkçe ders kitabında $(f=4) ; 7$. Sınıf Türkçe ders kitabında $(f=2) ; 8$. Sınıf Türkçe ders kitabında $(f=6)$ noktada yaratıcı düşünmeye yönelik ifadeler bulunmaktadır.

Yaratıcı düşünmenin, alt başlıklar açısından ortaokul Türkçe ders kitaplarındaki dağılımı ise 5. sınıftan 8. sınıfa doğru "olaylara farklı bakış açısıyla bakabilme $(f=0 ; f=3 ; f=2 ; f=3)$; hayal gücünü kullanma $(f=0 ; f=1 ; f=0 ; f=2)$ " şeklindedir. Yaratıcı düşünmenin alt başlıklarından "yeni, farklı bilgiler ve ürünler ortaya koyma; sorunlara kendine özgü çözümler bulabilme; konu veya durumla ilgili çok sayıda düşünce üretme; bir kavramı kendime göre tanımlayıp yorumlama" alt başlıklarına ilişkin ders kitaplarında herhangi bir ifadeye rastlanmamıştır. 


\section{Yaratıcı Düşünmeye Yönelik Türkçe Ders Kitaplarından Örnekler}

Örnek 1. Ara sıra alt kattaki komşumuz müzik setinin sesini anormal bir şekilde açıyor. Keşke her gün yapsa bunu, diyorum. Böylece ben de bir komşum olduğunu, yalnız olmadığımı, bana yakın bir yerde, hemen alt katımda insanların yaşadığını, istesek sesimizi birbirimize ulaştırabileceğimizi düşünüp mutlu olurdum. (8. sınıf)

Alt Başlık: Olaylara farklı bakış açısıyla bakabilme.

Örnek 2. Fabrikaya ev demek kimsenin aklından geçmez, çiftçilerin bir bakıma evidir fabrika. (7. sinif)

Alt Başlık: Olaylara farklı bakış açısıyla bakabilme.

Örnek 3. Ah, büyülü bir sopam olsa! Gördüğüm her dil yanlışına, özenti hâline gelmiş her yabancı sözcük kullanımına dokunuversem ve pırıl pırıl Türkçe çıkıverse ortaya. Ardından gözleri mutluluktan ışıldayan ve sorunlarını konuşarak çözebilen insanlar belirirdi herhâlde. (6. sınıf)

Alt Başlık: Hayal gücünü kullanma.

\section{Ortaokul Türkçe Ders Kitaplarındaki Metinlerde İletişim Kurmaya Ilişkin Bulgular}

Ortaokul Türkçe Ders Kitaplarındaki metinlerde temel becerilerden iletişim kurmaya ilişkin bulgular aşağıdaki tabloda verilmiştir.

Tablo 3. Ortaokul Türkçe Ders Kitaplarında Temel Becerilerden Illetişim Kurmaya İlişkin Bulgular

\begin{tabular}{|l|c|c|c|c|}
\hline \multicolumn{1}{|c|}{ Alt Beceriler } & 5. Sınıf & 6. Sınıf & 7. Sınıf & 8. Sinıf \\
\cline { 2 - 5 } & $f$ & $f$ & $f$ & $f$ \\
\hline uygun olarak kullanması gereken konuşma üslubunu belirleme & 0 & 1 & 0 & 1 \\
\hline uygun şekilde hitap etme & 0 & 0 & 0 & 0 \\
\hline aktif olarak dinleme & 0 & 0 & 0 & 0 \\
\hline grup içerisinde arkadaşlarıyla iletişim içinde olma & 0 & 2 & 0 & 0 \\
\hline Toplam & 0 & 3 & 0 & 1 \\
\hline
\end{tabular}

Tablo 3'te Türkçe Dersi Öğretim Programı'nda belirtilen temel becerilerden iletişim kurmanın ortaokul ders kitaplarındaki dağılımı verilmektedir. Toplam değerlere bakıldığında 5. sınıf ve 7. sınıf Türkçe ders kitaplarında iletişim kurmaya ilişkin herhangi bir ifade görülmemektedir. 6. sınıf Türkçe ders kitabında $(f=3)$ ve 8 . sınıf Türkçe ders kitabında $(f=1)$ noktada temel becerilerden iletişim kurmaya yönelik ifadeler bulunmaktadır.

İletişim kurmanın, alt başlıklar açısından ortaokul Türkçe ders kitaplarındaki dağılımı 5. sınıftan 8. sınıfa doğru "uygun olarak kullanması gereken konuşma üslubunu belirleme $(f=0 ; f=1 ; f=0$; $f=1$; grup içerisinde arkadaşlarıyla iletişim içinde olma $(f=0 ; f=2 ; f=0 ; f=0)$ " şeklindedir. İletişim kurmanın alt başlıklarından "uygun şekilde hitap etme; sorunlara kendine özgü çözümler bulabilme; konu veya durumla ilgili çok sayıda düşünce üretme; aktif olarak dinleme" maddelerine ilişkin ders kitaplarında herhangi bir ifadeye rastlanmamıştır. 


\section{İletişim Kurmaya Yönelik Türkçe Ders Kitaplarından Örnekler}

Örnek 1. Güzel bir ormanda çeşit çeşit hayvanlar barış içerisinde yaşıyormuş. Bu hayvanlardan dördü arkadaş olmuş. Bunlar; ceylan, kaplumbağa, karga ve fareymiş. Günlerini güle oynaya arkadaşça geçirmeye başlamışlar.

Alt Başık: Grup içerisinde arkadaşlarıyla iletişim içinde olma.

Örnek 2. Jimmy ve babam tüm bu ameliyatlara birlikte gidip gelirken çok iyi arkadaş olmuşlar.

Alt Başlık: Grup içerisinde arkadaşlarıyla iletişim içinde olma.

Örnek 3. Ali Kuş̧̧u, elçi olarak Osmanlı Padişahı Fatih Sultan Mehmet'in huzuruna çıktı ve Fatih hiçbir elçiye göstermediği iltifatı ona gösterdi. Onunla uzun uzun sohbet etti. Bunun nedenini soranlara ise şu yanıtı verecekti:

"Ben ona Uzun Hasan'ın elçisi olduğu için değil bir ilim güneşi olduğu için iltifat ettim."

Alt Başlık: Uygun olarak konuma üslubunu belirleme.

\section{Ortaokul Türkçe Ders Kitaplarındaki Metinlerde Problem Çözmeye iliş̧in Bulgular}

Ortaokul Türkçe Ders Kitaplarındaki metinlerde temel becerilerden problem çözmeye ilişkin bulgular aşağıdaki tabloda verilmiştir.

Tablo 4. Ortaokul Türkçe Ders Kitaplarında Temel Becerilerden Problem Çözmeye İlişkin Bulgular

\begin{tabular}{|l|c|c|c|c|}
\hline \multicolumn{1}{|c|}{ Alt Beceriler } & 5. Sınıf & 6. Sınıf & 7. Sınıf & 8. Sınıf \\
\cline { 2 - 5 } & $\mathrm{f}$ & $\mathrm{f}$ & $\mathrm{f}$ & $\mathrm{f}$ \\
\hline problemi sezme & 1 & 1 & 0 & 0 \\
\hline problemi belirleme & 1 & 0 & 0 & 0 \\
\hline problemin çözümü için çözüm yolları üretme & 4 & 2 & 0 & 1 \\
\hline çözümün işe yararlığını belirleme & 1 & 1 & 0 & 1 \\
\hline Toplam & 7 & 4 & 0 & 2 \\
\hline
\end{tabular}

Tablo 4'te Türkçe Dersi Öğretim Programı'nda belirtilen temel becerilerden problem çözmenin ortaokul ders kitaplarındaki dağılımı verilmektedir. Toplam değerlere bakıldığında 5. sınıf Türkçe ders kitabında $(f=7) ; 6$. sınıf Türkçe ders kitabında $(f=4) ; 7$. sınıf Türkçe ders kitabında $(f=0)$ ve 8. sınıf Türkçe ders kitabında $(f=2)$ noktada temel becerilerden problem çözmeye yönelik ifadeler bulunmaktadır.

Problem çözmenin, alt başlıklar açısından ortaokul Türkçe ders kitaplarındaki dağılımı ise 5. sınıftan 8. sınıfa doğru "problemi sezme $(f=1 ; f=1 ; f=0 ; f=0)$; problemi belirleme $(f=1 ; f=0 ; f=0 ; f=0)$; problemin çözümü için çözüm yolları üretme $(f=4 ; f=2 ; f=0 ; f=1)$; çözümün işe yararlığını belirleme $(f=1 ; f=1 ; f=0 ; f=1)^{\prime \prime}$ şeklindedir. 
Ortaokul Türkçe Ders Kitaplarının Türkçe Dersi Öğretim Programındaki Temel Beceriler Açısından İncelenmesi

\section{Problem Çözmeye Yönelik Türkçe Ders Kitaplarından Örnekler}

Örnek 1. O yıllarda Fransa'da Louis Pasteur (Lui Pastör) adında bir bilim insanı yaşıyordu. Pasteur, yıllardan beri hastalıklar üzerinde incelemeler yapmaktaydı. Bütün hastalıklara mikrop denilen küçük canlıların neden olduğunu düşünüyor, düşüncesinin doğruluğunu ispata çalışıyordu.

Alt Başlık: Problemi sezme.

Örnek 2. Pasteur, aynı yoldan şarbon hastalığına karşı koyabileceğini düşündü. Zayıf şarbon mikropları üretti. Bu mikroplarla hayvanların bazılarını şarbondan koruyabileceğini tahmin ediyordu.

Alt Başlık: Problemin çözümü için çözüm yolları üretme.

Örnek 3. Ertesi sabah, büyük bir kalabalık, koyunları görmeye çayıra koştu. Zayıf mikrop aşılanmış olan yirmi beş koyun sakin sakin otluyordu; hiçbir şeyleri yoktu! Pasteur'ün deneyi başarı kazanmıştı. Şarbon mikroplarıla yapılan bu deney, birçok hastalığa mikropların neden olduğunu kanıtladı.

Alt Başık: Çözümün işe yararlığını belirleme.

Örnek 4. Üç arkadaş, ceylanı kurtarmaları gerektiğine karar vermiş. Hemen bir plan yapmışlar. Yaptıkları plana göre, aralarından ikisi vakit kaybetmeden ceylanı kurtarmaya gidecek, kalan bir kişi de evi bekleyecekmiş. Planı hemen uygulamaya koymuşlar.

Alt Başlık: Problemin çözümü için karar verme.

Örnek 5. Hep birlikte gidip demir madenini gördüler. Demircinin sözlerini de beğendiler. Dağın geniş yerine bir kat odun, bir kat da kömür dizdiler. Sonra da dağın üstünü, arka yanını, öte yanını ve beri yanını bir sıra odun ve bir sıra kömürle doldurduktan sonra yetmiş deriden, yetmiş körük yapıp yetmiş yerde kurdular; odunlarla kömürleri ateşleyip körüklediler.

Alt Başlık: Problemin çözümü için çözüm yolları üretme.

\section{Ortaokul Türkçe Ders Kitaplarındaki Metinlerde Araştırma-Sorgulamaya iliş̧kin Bulgular}

Ortaokul Türkçe Ders Kitaplarındaki metinlerde temel becerilerden araştırmaya eleştirel düşünmeye ilişkin bulgular aşağıdaki tabloda verilmiştir.

Tablo 5. Ortaokul Türkçe Ders Kitaplarında Temel Becerilerden Araştırmaya iliş̧kin Bulgular

\begin{tabular}{|l|c|c|c|c|}
\hline \multicolumn{1}{|c|}{ Alt Beceriler } & 5. Sınıf & 6. Sınıf & 7. Sınıf & 8. Sınıf \\
\cline { 2 - 5 } & $\mathrm{f}$ & $\mathrm{f}$ & $\mathrm{f}$ & $\mathrm{f}$ \\
\hline anlamlı tahminlerde bulunma & 1 & 4 & 0 & 1 \\
\hline yeni gelişmelere karşı meraklı olma & 1 & 0 & 0 & 0 \\
\hline uygun araştırma ortamına karar verme & 0 & 0 & 0 & 0 \\
\hline araştırmayı planlama & 0 & 0 & 0 & 0 \\
\hline uygun araç gereç ve kaynak kullanma & 0 & 0 & 0 & 0 \\
\hline Toplam & 2 & 4 & 0 & 1 \\
\hline
\end{tabular}


Tablo 5'te Türkçe Dersi Öğretim Programı'nda belirtilen temel becerilerden araştırmanın ortaokul Türkçe ders kitaplarındaki dağılımı verilmektedir. Toplam değerlere bakıldığında 5. sınıf Türkçe ders kitabında $(f=2) ; 6$. sınıf Türkçe ders kitabında $(f=4)$; 7 . sınıf Türkçe ders kitabında $(f=0)$ ve 8. sınıf Türkçe ders kitabında $(f=1)$ noktada temel becerilerden araştırmaya yönelik ifadeler bulunmaktadır.

Temel becerilerden araştırmanın, alt başlıklar açısından ortaokul Türkçe ders kitaplarındaki dağılımı ise 5. sınıftan 8. sınıfa doğru "anlamlı tahminlerde bulunma $(f=1 ; f=4 ; f=0 ; f=1)$; yeni gelişmelere karşı meraklı olma $(f=1 ; f=0 ; f=0 ; f=0)$ şeklindedir. Araştırmanın alt başlıklarından "uygun araştırma ortamına karar verme, araştırmayı planlama, uygun araç gereç ve kaynak kullanma" maddelerine ilişkin Türkçe ders kitaplarındaki metinlerde herhangi bir unsura rastlanmamıştır.

\section{Temel Becerilerden Araştırma-Sorgulamaya Yönelik Türkçe Ders Kitaplarından Örnekler}

Örnek 1. Yazarın birkaç yerde, cümleleri tekrar ettiğini görüyoruz. Söz konusu noktalarda amaç, anlamı güçlendirmek ve o ana, kişiye ya da duruma vurgu yapmak diye düşünülebilir. Belki de bu durumu onun şairliğine dayandırmalıyız. Sesleri tekrar ederek bir ahenk yaratmak da istemiş olabilir.

Alt Başlık: Anlamlı tahminlerde bulunma.

Örnek 2. Nasıl olsa boldur, her köşe başında bir su kaynağı bulunur veya sanki “Herkes suya yeterince önem veriyor, ben önem vermesem ne olur? diye düşünürler belki de.

Alt Başlık: Anlamlı tahminlerde bulunma.

Örnek 3. Kuş tüyleri ve kamışla başlayan öykü, tükenmez kalemlerin bulunuşuna kadar sürmüştür. Kim bilir, belki de öykünün bundan sonraki kısmı, geleceğin buluş̧̧uları tarafından yazılacaktır.

Alt Başlık: Yeni gelişmelere karşı meraklı olma.

Örnek 4. Çok para var bu işte... Üniversiteye hazırlık kursları kadar iş yapar, bundan eminim. Alt Başlık: Anlamlı tahminlerde bulunma.

\section{Ortaokul Türkçe Ders Kitaplarındaki Metinlerde Bilgi Teknolojilerini Kullanmaya iliş̧in}

\section{Bulgular}

Ortaokul Türkçe Ders Kitaplarındaki metinlerde temel becerilerden bilgi teknolojilerini kullanmaya ilişkin bulgular aşağıdaki tabloda verilmiştir. 
Ortaokul Türkçe Ders Kitaplarının Türkçe Dersi Öğretim Programındaki Temel Beceriler Açısından İncelenmesi

Tablo 6. Ortaokul Türkçe Ders Kitaplarında Temel Becerilerden Bilgi Teknolojilerini Kullanmaya İlişkin Bulgular

\begin{tabular}{|l|c|c|c|c|}
\hline \multicolumn{1}{|c|}{ Alt Beceriler } & 5. Sinıf & 6. Sinıf & 7. Sinıf & 8. Sinıf \\
\cline { 2 - 5 } & $\mathrm{f}$ & $\mathrm{f}$ & $\mathrm{f}$ & $\mathrm{f}$ \\
\hline kullanılacak bilgi teknolojisine karar verme & 0 & 0 & 0 & 0 \\
\hline bilgi teknolojilerini kullanırken planlama yapma & 1 & 0 & 0 & 0 \\
\hline bilgi teknolojilerini kullanmak gerekli becerilere sahip olma & 4 & 0 & 0 & 0 \\
\hline teknolojiyi kullanarak bilgi elde etme & 2 & 0 & 0 & 0 \\
\hline Toplam & 7 & 0 & 0 & 0 \\
\hline
\end{tabular}

Tablo 6'da Türkçe dersi öğretim programında yer alan temel becerilerden bilgi teknolojilerini kullanmanın ortaokul Türkçe ders kitaplarındaki yerine ilişkin sayısal değerler bulunmaktadır. Bu verilere göre çalışmada incelenen kitaplardan ortaokul 5. Sınıf ders kitabında toplam 7 noktada bilgi teknolojilerini kullanmaya yönelik ifadeler bulunmaktadır. 6. 7. ve 8. sınıf Türkçe ders kitaplarında bilgi teknolojilerini kullanmayla ilgili herhangi bir ifade tespit edilememiştir.

\section{Bilgi Teknolojilerini Kullanmaya Yönelik Türkçe Ders Kitaplarından Örnekler}

Örnek 1. Ama makineden para çekmeye hazır değilim daha. Benim gibilerin tamam», kartı cebinde taşlıyorlar. Gençlerse sabah akşam makinenin başında.

Alt Başlık: Bilgi teknolojilerinin kullanılması için gerekli becerilere sahip olma.

Örnek 2. Kartımı "ok yönü içeri gelecek şekilde" makineye takıp "GiRiş" tuşuna bastım. Makinenin monitöründe, "Hoş geldiniz Sayın Selahattin Duman" diye bir yazı belirdi. Düşünmeden "Hoş bulduk efendim." diye mırıldandım. Ben lafımı bitirir bitirmez ekrana, "işleminiz devam ediyor, lütfen bekleyiniz." yazısı geldi. Makine resmen konuşuyor! Üstelik söylediklerimi de duyuyor! Hemen toparlandım. "Zaten acelem yok. Beklerim." dedim.

Alt Başlık: Bilgi teknolojilerinin kullanılması için gerekli becerilere sahip olma.

Örnek 3. Bell, her iki atölye odasına üçer verici ve alıcı koymuştu. Cereyan bağlanınca mıknatısların iki kutbunu birleştiren saç levhalar titreşecekti.

Alt Başlık: Bilgi teknolojilerini kullanırken planlama yapma.

Örnek 4. Uzay çalışmalarında insan yapımı birçok uydudan da yararlanılır. Bu uydular doğrudan uzaydan bilgi toplayıp dünyadaki bilim insanlarına aktarırlar.

Alt Başlık: Teknolojiyi kullanarak bilgi elde etme.

\section{Ortaokul Türkçe Ders Kitaplarındaki Metinlerde Karar Vermeye İlişkin Bulgular}

Ortaokul Türkçe Ders Kitaplarındaki metinlerde temel becerilerden karar vermeye eleştirel düşünmeye ilişkin bulgular aşağıdaki tabloda verilmiştir. 
Tablo 7. Ortaokul Türkçe Ders Kitaplarında Temel Becerilerden Karar Vermeye İlişkin Bulgular

\begin{tabular}{|l|c|c|c|c|}
\hline \multicolumn{1}{|c|}{ Alt Beceriler } & 5. Sınıf & 6. Sınıf & 7. Sınıf & 8. Sınıf \\
\cline { 2 - 5 } & $\mathrm{f}$ & $\mathrm{f}$ & $\mathrm{f}$ & $\mathrm{f}$ \\
\hline bağımsız olarak karar verme sorumluluğu üstlenme & 0 & 0 & 0 & 0 \\
\hline olası seçenekler üretme ve bunlar hakkında bilgi toplama & 0 & 0 & 0 & 0 \\
\hline seçeneklerin olumlu, olumsuz yönleri hakkında bilgi toplama & 0 & 0 & 0 & 0 \\
\hline karar vermede başkalarının duygu ve düşüncelerini dikkate alma & 0 & 0 & 0 & 0 \\
\hline Toplam & 0 & 0 & 0 & 0 \\
\hline
\end{tabular}

Tablo 7'de Türkçe dersi öğretim programında yer alan temel becerilerden karar vermenin ortaokul Türkçe ders kitaplarındaki yerine ilişkin sayısal değerler bulunmaktadır. Bu verilere göre çalışmada incelenen Türkçe ders kitaplarında karar vermeyle ilgili herhangi bir ifade tespit edilememiştir.

\section{Ortaokul Türkçe Ders Kitaplarındaki Metinlerde Girişimciliğe ilişkin Bulgular}

Ortaokul Türkçe Ders Kitaplarındaki metinlerde temel becerilerden girişimciliğe eleştirel düşünmeye ilişkin bulgular aşağıdaki tabloda verilmiştir.

Tablo 8. Ortaokul Türkçe Ders Kitaplarında Temel Becerilerden Girişimciliğe iliş̧kin Bulgular

\begin{tabular}{|l|c|c|c|c|}
\hline \multicolumn{1}{|c|}{ Alt Beceriler } & 5. Sınıf & 6. Sınıf & 7. Sınıf & 8. Sınıf \\
\cline { 2 - 5 } & $\mathrm{f}$ & $\mathrm{f}$ & $\mathrm{f}$ & $\mathrm{f}$ \\
\hline empati kurma & 0 & 0 & 0 & 0 \\
\hline insan ilişkilerinde uyumlu davranışlar gösterme & 0 & 0 & 0 & 0 \\
\hline plan yapma ve planlarını uygulayabilme & 0 & 0 & 0 & 0 \\
\hline risk alma & 0 & 0 & 0 & 0 \\
\hline amacına ulaşmak için harekete geçme & & & & \\
\hline Toplam & 0 & 0 & 0 & 0 \\
\hline
\end{tabular}

Tablo 8'de Türkçe dersi öğretim programında yer alan temel becerilerden girişimciliğin ortaokul Türkçe ders kitaplarındaki yerine ilişkin sayısal değerler bulunmaktadır. Bu verilere göre çalışmada incelenen Türkçe ders kitaplarında girişimcilikle ilgili herhangi bir ifade tespit edilememiştir.

\section{Tartışma ve Sonuç}

Günümüzde eğitim öğretim faaliyetleri öğrencilere sadece bilgi vermeye yönelik değil, aynı zamanda hayatta karşılaşabilecekleri çeşitli durumlarda nasıl davranmaları gerektiğine yönelik beceriler edindirmeyi amaçlayan bir süreç olarak düzenlemektedir. Dolayısıyla iyi düzenlenmiş eğitim öğretim etkinlikleri öğrenciye, edindiği bilgileri nasıl kullanacağını kazandırması açısından önem taşımaktadır. Bu durum eğitimin ilkelerinden hayatilik ilkesi ile de yakından bağlantılıdır. Bu ilkeye göre öğretme öğrenme etkinlikleri bireyin yaşamda karşılaşacağı problemlere ve durumlara yönelik olmalı; aynı zamanda öğrencinin yaşamla bağlantısını kurmalıdır. Genel olarak okuma, dinleme, 
konuşma ve yazma becerilerini geliştirmek amacıyla okutulan Türkçe derslerinin bir diğer amacı da öğrenciyi hayata hazırlamaktır. Bu amaca ulaşabilmek için 2005 Türkçe Dersi Öğretim Programı́nda bazı temel becerilere yer verilmiştir. Bu beceriler günlük hayatta öğrencinin eleştirel düşünmesini, yaratıcı düşünmesini ve bunlar yoluyla problem çözme yeteneğini geliştirmesini, girişimci bir kişiliğe sahip olmasını, doğru, sağlıklı iletişimler kurmasını, bilgi teknolojilerinden yararlanmasını amaçlamaktadır. 2005 Türkçe Dersi Öğretim Programı'nda yer alan temel becerilerin Türkçe ders kitaplarında hangi düzeyde kullanıldığını tespit etmek amacıyla gerçekleştirilen bu araştırmada ulaşılan sonuçlar şu şekilde özetlenebilir.

\section{Eleştirel Düşünme Becerisine Yönelik Sonuçlar}

Bilginin sadece edinilmesinin değil, aynı zamanda kullanımının da önem kazandığı günümüzde düşünen, eleştiren, üreten, bilgiye ulaşma yollarını bilen bireyler yetiştirilmeye çalışılmakta, öğrencilere düşünme becerilerini kazandırmaya yönelik eğitim programları hazırlanmaktadır (Akbıyık ve Seferoğlu, (91). Eleştirel düşünebilme ve etkili kararlar alabilme, eğitimli bir bireyin sahip olması gereken bilişsel becerilerdir (NCEE, 1988). Epstein'e göre (1999) eleştirel düşünme, çok fazla bilginin ve bizi ikna etmeye çalışan çok fazla kişinin olduğu dünyaya karşı bir savunmadır. Eleştirel düşünme yeteneği, bireyleri doğrulanmamış iddia ve düşünceler arasında bocalamaktan kurtarır. Eleştirel düşünme bilgi üretimini hareket ettiren motordur. Demokratik bir toplumda bireylerin eleştirel düşünme becerilerine sahip olmaları, eleştirel düşünme ve karar verme becerilerini karşılaştıkları karmaşık sosyal problemlerin çözümünde kullanmaları çok önemlidir.

Türkçe dersi öğrenciye; doğru ve güzel okuma / yazma, etkili dinleme, dil bilgisi kurallarını uygulatma veya etkili konuşma (Şen, 2009: 764) gibi temel dil becerilerini kazandırmanın yanında eleştirel düşünme, yaratıcı düşünme, iletişim kurma, problem çözme, araştırma, karar verme gibi temel becerilerini de kazandırmayı hedeflemektedir. Öğrencilerde eleştirel düşünme becerisinin en iyi kazandırılacağı derslerin başında Türkçe dersi gelmektedir. Eleştirel düşünme, araştırma kapsamında incelenen ders kitaplarında çok düzensiz bir dağııım göstermektedir. Örneğin 5. sınıf düzeyinde $(f=20) ; 6$. sınıf düzeyinde $(f=42) ; 7$. sınıf düzeyinde $(f=8)$ ve 8 . sınıf düzeyinde $(f=13)$ olarak tespit edilmiştir. Bu düzensiz dağılımın yanı sıra eleştirel düşünme becerisinin özellikle 7. ve 8. sınıflar düzeyinde çok az yer aldığını söylemek mümkündür. Burada beklenen durum 5. sınıf düzeyinden 8 . sınıf düzeyine doğru yükselen bir grafik çizilmesidir. Ancak ulaşılan bulgulara göre beklenen durumun aksi yönünde bir sonuca varılmıştır. Eleştirel düşünme becerisinin ders kitaplarında kullanımıyla ilgili dikkat edilmesi gereken başka bir husus 7. ve 8. sınıf düzeyleriyle ilgilidir. Bu sınıf düzeylerindeki öğrencilerin yaşları soyut düşünmenin başladığı yaşlardır. Bu nedenle öğrencinin bilişsel gelişimiyle paralel olması açısından eleştirel düşünme gibi soyut düşünme yeterliliklerini gerektiren bir becerinin 
bu sınıf düzeylerinde daha fazla ele alınması beklenir. Ancak bu noktada da beklenen durumun değil tersi bir sonucun varlığı tespit edilmiştir.

\section{Yaratıcı Düşünme Becerisine Yönelik Sonuçlar}

Yaratıcı düşünce zihinsel yönden sağlıklı olabilmek açısından önemli olduğu kadar, eğitimde ve mesleki alanda başarı için de gerekli olan bir beceridir (Torrance, 1965). Bireyler olayları, durumları farklı bakış açılarından değerlendirebilmeyi; problemlere değişik ve etkili çözümler geliştirebilmeyi yaratıcı düşünme sayesinde gerçekleştirebilirler. Karakuş (2001) bilginin çok hızlı gelişip, değiştiği bu çağda toplumların bu değişim hızını yakalayabilmesi için aktif, düşünen, yaratan, sorun çözen ve kendini sürekli yenileyebilen bireylere ihtiyaç olduğunu, bu özellikteki insanların yetişebilmesi için de eğitim programlarının bu yönde hazırlanması gerektiğini belirtmektedir. Çalışmada incelenen ders kitaplarında yaratıcı düşünmenin oldukça yetersiz bir şekilde yer aldığı görülmektedir. Yaratıcı düşünmenin ders kitaplarındaki toplam değerlerine bakıldığında 5. sınıf düzeyinde kullanılmadığı, 6 . sınıf düzeyinde $(f=4) ; 7$. sınıf düzeyinde $(f=2)$ ve 8 . sınıf düzeyinde $(f=6)$ noktada yaratıcı düşünmeye yer verildiği tespit edilmiştir. Bu durum öğrencilere yaratıcı düşünmenin kazandırılması açısından Türkçe ders kitaplarının çok yetersiz olduğunu göstermektedir. Benzer bir durum yaratıcı düşünmenin alt becerileri açısından da söz konusudur. Buna göre alt becerilerden "olaylara farklı bakış açısıyla bakabilme" ile "hayal gücünü kullanma" maddelerine düşük bir oranda yer verilmiş, diğer alt başlıklar olan "yeni, farklı bilgiler ve ürünler ortaya koyma; sorunlara kendine özgü çözümler bulabilme; konu veya durumla ilgili çok sayıda düşünce üretme; bir kavramı kendime göre tanımlayıp yorumlama" alt başıklarına ise hiç yer verilmemiştir. Bu durum, Türkçe ders kitaplarının yaratıcı düşünmeye daha çok yer veren metinlerle desteklenmesi gerektiği anlamına gelmektedir.

\section{İletişim Kurma Becerisine Yönelik Sonuçlar}

Türkçe dersleri bünyesinde özellikle konuşma ve yazma becerileri öğrencilerin kendilerini gerek günlük hayatta gerek hazırlıklı ortamlarda etkili, açık ve anlaşılır bir şekilde ifade etmelerini sağlamak amacıyla kazandırımaya çalışımaktadır. Bu durum, öğrencilerin sağlıklı iletişim süreçleri kurma becerilerini geliştirmek amacıyla düzenlenmektedir. Bu amaçla düzenlenen sınıf içi etkinliklerin ders kitaplarındaki metinler yoluyla desteklenmesi gerekmektedir. Bu açıdan bakıldığında Türkçe Dersi Öğretim Programı́nda yer alan temel becerilerden iletişim kurmanın ortaokul ders kitaplarındaki dağııımının, öğrencilerin etkili iletişim kurma becerilerini desteklemekte yeterli olmadığı görülmektedir. Toplam değerlere bakıldığında 5. sınıf düzeyinde $(f=0) ; 6$. sınıf düzeyinde $(f=3)$; 7. sınıf düzeyinde $(f=0)$ ve 8 . sınıf düzeyinde $(f=1)$ noktada temel becerilerden iletişim kurmaya yönelik ifadeler bulunmaktadır. 


\section{Problem Çözme Becerisine Yönelik Sonuçlar}

Problem çözme temel becerisi, eleştirel ve yaratıcı düşünmeden sonra üçüncü sırada kullanılan temel beceri olmasına rağmen ders kitaplarında istenen düzeyde yer almadığı gibi bir sonuca varılabilir. 5 . sınıf düzeyinde $(f=7) ; 6$. sınıf düzeyinde $(f=4) ; 7$. sınıf düzeyinde $(f=0)$ ve 8 . sınıf düzeyinde $(f=2)$ noktada temel becerilerden problem çözmeye yönelik ifadeler bulunmaktadır. Gömleksiz ve Kan (2007: 62) tarafından 2005 Türkçe Dersi Öğretim Programı́nın problem çözme ve karar verme becerilerinin gelişmesi üzerindeki etkilerine yönelik olarak yapılan araştırmada, öğrencilerin programın problem çözme ve karar verme becerilerini kazandırmada etkili olduğunu düşündükleri ortaya çıkmıştır. Buna karşın Türkçe ders kitaplarındaki metinlerde problem çözme becerisine çok az oranda yer verilmesi düşündürücüdür.

\section{Araştırma Becerisine Yönelik Sonuçlar}

Temel becerilerden araştırma, ortaokul Türkçe ders kitaplarında oldukça az yer verilmektedir. Araştırma becerisine ilişkin sayısal değerlerin sınıf düzeyi yükseldikçe farklı dağıımlar gösterdiği de çalışmada ulaşılan sonuçlardandır. 5. sınıf Türkçe ders kitabında $(f=2)$ yerde rastlanan araştırma becerisi; 6. Sınıf düzeyinde $(f=4)$; 7. sınıf düzeyinde $(f=0)$ ve 8 . sınıf düzeyinde $(f=1)$ yerde araştırma becerisine yer verilmektedir. Araştırma becerisine ilişkin bir diğer dikkat çekici sonuç da alt becerilerden "uygun araştırma ortamına karar verme, araştırmayı planlama, uygun araç gereç ve kaynak kullanma" nın ders kitaplarında hiç yer almamasıdır.

\section{Bilgi Teknolojilerini Kullanma Becerisine Yönelik Sonuçlar}

Temel becerilerden bilgi teknolojilerini kullanma becerisinin, çalışmada incelenen ders kitaplarından 5. sınıf düzeyinde $(f=7)$ noktada kullanıldı̆̆ı; 6. 7. ve 8. sınıf düzeylerinde ise bu beceriye ilişkin herhangi bir ifadeye rastlanmadığı sonucuna ulaşılmıştır. Günümüz dünyasında çağdaş yurttaşlık becerileri; bilgiye erişme becerisi, bilgiyi amaçlarına uygun şekilde kullanabilme becerisi ve muazzam genişlikteki bilgileri analiz edebilme becerilerini içermektedir. Bunlar ise, doğrudan doğruya, bilgisayar ve teknoloji kullanımı ile elde edilebilir. Teknoloji kullanımı, öğrencilerin öğrenme sürecine odaklanmalarını teşvik eder. Böylece; öğrencilerin motivasyonu ile kendilerine olan güvenlerini arttırarak onların bilişsel becerilerinin de gelişmesini sağlar (Braun, 1999: 349; Heafner, 2004: 47, akt. Kaya, 2008: 192). Çağdaş toplumda başarılı bir öğrencinin sahip olması gereken becerileri Tor ve Erden (2004: 122) "bilgi teknolojilerindeki araçları ustalıkla kullanabilme, veri toplama, yorumlama ve bu verileri kullanabilme, uygun bilgi teknolojileri kaynaklarını kullanarak çalışma yapabilme şeklinde sıralamaktadır. Öğrencilerin belirtilen yeterlilikler doğrultusunda yetiştirilebilmeleri için her ders kendi üzerine düşen sorumluluğu yerine getirecek şekilde 
okutulmalıdır. Türkçe dersleri de temel gereçlerden olan metinler yoluyla öğrencilerin bilgi teknolojilerinin farkında olmaları ve bunları uygun bir şekilde kullanmaları doğrultusunda yönlendirmelerde bulunmalıdır. Ancak bu durumun ders kitaplarına seçilen mevcut metinler yoluyla yapılması oldukça zor görünmektedir.

\section{Karar Verme ve Girişimcilik Becerisine Yönelik Sonuçlar}

Çalışmada incelenen Türkçe ders kitaplarında karar verme ve girişimcilik temel becerilerine özel olarak değinmek gerekir. Çünkü bu iki beceri de ders kitaplarındaki metinlerde hiçbir alt beceri doğrultusunda tespit edilememiştir. Bu durum, Türkçe ders kitapları açısından üzerinde dikkatli bir şekilde düşünmeyi gerektirmektedir. Günlük hayatta bireylerin en çok ihtiyaç hissedecekleri becerilerden ikisi olma özelliği gösteren karar verme ve girişimciliğin öğrencilere kazandırılması amacıyla her fırsatta uygun etkinlikler düzenlenmesi gerekirken Türkçe ders kitaplarına seçilen metinlerde 5. sınıf düzeyinden 8. sınıf düzeyine kadar bu becerilere yer verilmemiş olması önemli bir eksikliktir.

Sonuç olarak araştırmaya konu olan ortaokul Türkçe ders kitaplarının 2005 Türkçe Dersi Öğretim Programı'nda belirtilen temel beceriler açısından oldukça yetersiz olduğu söylenebilir. Hatta girişimcilik ve karar verme becerilerinin ders kitaplarındaki metinlerde hiç kullanılmadığı görülmektedir. Eleştirel düşünme, yaratıcı düşünme, problem çözme gibi bazı temel becerilerin de ders kitaplarında alt beceriler açısından düzensiz bir dağılım gösterdiği tespit edilmiştir. Buna göre ders kitapları yazarlarının metin seçiminde öğretim programında yer alan temel becerileri göz önünde bulundurmaları gerekmektedir. 


\section{Kaynakça}

Akbıyık, C. - Seferoğlu, S. S. (2006). Eleştirel Düşünme Eğilimleri ve Akademik Başarı. Çukurova Üniversitesi Eğitim Fakültesi Dergisi. C. 32, S. 2, 90-99.

Alacalı, O. (2013). İlköğretim 5. Sınıf Türkçe Ders Kitabı. Ankara: Ada Yayıncılık.

Bıyıklı, H. - Öztaş, Y. (2012). İlköğretim 6. Sınıf Türkçe Ders Kitabı. Ankara: Doku Yayınları.

Cüceloğlu, D. (2001). Iyi Düşün Doğru Karar Ver. İstanbul: Remzi Kitabevi.

Epstein, R. L. (1999). Critical Thinking, Belmont: Wadsworth Publishing Company.

Ersever, H. Ö. (1996). Karar verme becerileri kazandırma programının ve etkileşim grubu deneyiminin üniversite öğrencilerinin karar verme stilleri üzerindeki etkileri. Ankara Üniversitesi, Sosyal Bilimler Enstitüsü, Ankara, Yayınlanmamış Doktora Tezi.

Gömleksiz, M. N. - Kan A. Ü. (2009). Sosyal Bilgiler Dersi Öğretim Programının Eleştirel Düşünme, Yaratıcı Düşünme ve Girişimcilik Becerilerini Kazandırmadaki Etkililiğinin Belirlenmesi. 15. Eğitim Bilimleri Kongresi. 13-15 Eylül, Muğla.

Gültekin, M. (2004). Öğrenme Öğretme Sürecinde Yeni Yaklaşımlar. Anadolu Üniversitesi Eğitim Fakültesi Dergisi, 1 (14), 25-51.

Kapulu, A. - Karaca, A. (2012). Illköğretim 7. Sınıf Türkçe Ders Kitabı. Ankara: Koza Yayın Dağıtım.

Karasar, N. (2009). Bilimsel Araştırma Yöntemleri. Nobel Yayınevi , 23. Baskı

Kaya, B. (2008). Sosyal Bilgiler Dersinde Teknoloji Kullanımı. Gazi Üniversitesi Gazi Eğitim Fakültesi Dergisi, Cilt 28, Sayı 3, 189-205.

Köken, N. (2004). Düşünme ve Eğitim. Eğitime Iliş̧kin Çeşitlemeler I. (Edt. Musa Gürel). 109-129. Konya: Eğitim Kitabevi Yayınları.

Kurt, M. - Altay, J. - Kara, M. (2012). Illköğretim 8. Sınıf Türkçe Ders Kitabı. Ankara: Enderun Matbaacilık.

May, R. (1994). Yaratma Cesareti. (Çev. Alper Oysal). İstanbul: Metis Yayınları.

MEB (2005). Illköğretim Türkçe Dersi 6-8. Sınıflar Öğretim Programı. Milli Eğitim Bakanlığı Yayınları. Ankara.

Saban, A. (2000). Öğrenme Öğretme Süreci. Ankara: Nobel Yayın Dağıtım.

San, İ. (1979). Sanatsal Yaratma ve Çocukta Yaratıcılık. Ankara: Tisa Matbaası.

Sardoğan, M., Karahan, T. ve Kaygusuz, C. (2006). Üniversite Öğrencilerinin Kullandıkları Kararsızlık Stratejilerinin Problem Çözme Becerisi, Cinsiyet, Sınıf Düzeyi ve Fakülte Türüne Göre İncelenmesi. Mersin Üniversitesi Eğitim Fakültesi Dergisi. Cilt 2, Sayı 1, 78-97.

Semerci, N. (1999). Kritik düşünmenin mikro öğretim dersinde eleştiri becerisini geliştirmeye etkisi. Fırat Üniversitesi Sosyal Bilimler Enstitüsü, Yayımlanmamış Doktora Tezi, Elazığ.

Şen, Ü. (2009). Türkçe Öğretmeni Adaylarının Eleştirel Düşünme Tutumlarının Çeşitli Değişkenler Açısından Değerlendirilmesi. Zeitschrift für die Welt der Türken Journal of World of Turks. Vol 1, No: 2, 69-89.

TDK (1996). Türkçe Sözlük. Türk Dil Kurumu Yayınları. 
Tor, H. - Erden, O. (2004). Illköğretim Öğrencilerinin Bilgi Teknolojilerinden Yararlanma Düzeyleri Üzerine Bir Araştırma. The Turkish Online Journal Of Educational Technology - TOJET. Vol. 3, Issue 1. 120-130.

Torrance E. P. (1995). Why To Fly? A Philosophy Of Creativity. New Jersey: Norwood Alex. 
Ortaokul Türkçe Ders Kitaplarının Türkçe Dersi Öğretim Programındaki Temel Beceriler Açısından İncelenmesi

Ek 1. Türkçe Dersi Öğretim Programında Yer Alan Temel ve Alt Beceriler

\begin{tabular}{|c|c|}
\hline Temel Beceriler & Alt Beceriler \\
\hline 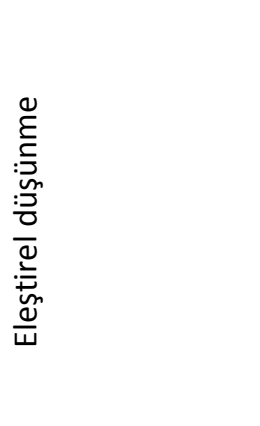 & $\begin{array}{l}\text { - olay, durum ve konulara sorgulayıcı gözle bakma, } \\
\text { - sebep-sonuç ilişkilerini bulma, } \\
\text { - benzerlik ve farklılıkları yakalama, } \\
\text { - çıkarımlarda bulunma, } \\
\text { - öğrendikleri arasında karşılaştırmalar yapma, } \\
\text { - okurken, dinlerken vb. zihninde sorular oluşturma ve cevaplar bulma, } \\
\text { - edindiği bilgileri sınıflandırma, }\end{array}$ \\
\hline 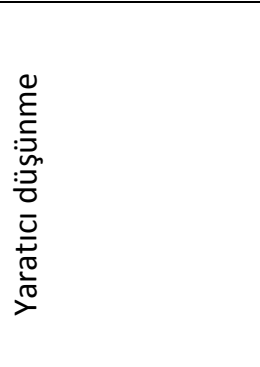 & $\begin{array}{l}\text { - yeni, farklı bilgiler ve ürünler ortaya koyma, } \\
\text { - olaylara farklı bakış açısıyla bakabilme, } \\
\text { - sorunlara kendine özgü çözümler bulabilme, } \\
\text { - konu veya durumla ilgili çok sayıda düşünce üretme, } \\
\text { - bir kavramı kendime göre tanımlayıp yorumlama, } \\
\text { - hayal gücünü kullanma }\end{array}$ \\
\hline 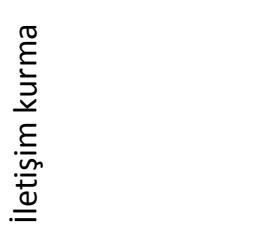 & $\begin{array}{l}\text { - uygun olarak kullanması gereken konuşma üslubunu belirleme, } \\
\text { - uygun şekilde hitap etme, } \\
\text { - aktif olarak dinleme, } \\
\text { - grup içerisinde arkadaşlarıyla iletişim içinde olma, }\end{array}$ \\
\hline 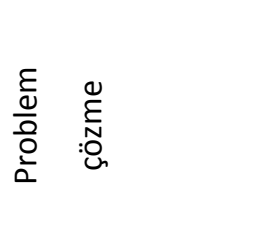 & $\begin{array}{l}\text { - problemi sezme, } \\
\text { - problemi belirleme, } \\
\text { - problemin çözümü için çözüm yolları üretme, } \\
\text { - çözümün işe yararlığını belirleme, }\end{array}$ \\
\hline 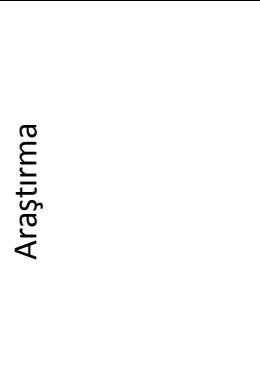 & $\begin{array}{l}\text { - anlamlı tahminlerde bulunma, } \\
\text {-yeni gelişmelere karşı meraklı olma } \\
\text { - uygun araştırma ortamına karar verme, } \\
\text { - bilimsel yaklaşımı kullanarak araştırmayı planlama, } \\
\text { - uygun araç gereç ve kaynak kullanma kullanma, } \\
\text { - bulguları uygun bir dille ifade etme, }\end{array}$ \\
\hline 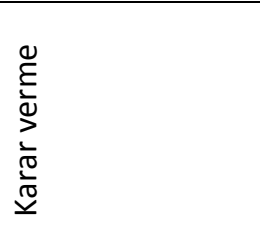 & $\begin{array}{l}\text { - bağımsız olarak karar verme sorumluluğu üstlenme, } \\
\text { - olası seçenekler üretme ve bunlar hakkında bilgi toplama, } \\
\text { - seçeneklerin olumlu ve olumsuz yönleri hakkında bilgi toplama, } \\
\text { - karar vermede başkalarının duygu ve düşüncelerini de dikkate alma, }\end{array}$ \\
\hline 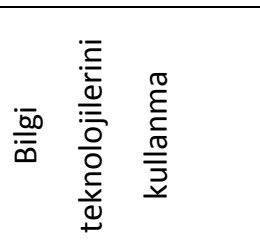 & $\begin{array}{l}\text { - kullanılacak bilgi teknolojisine karar verme, } \\
\text { - bilgi teknolojilerini kullanırken planlama yapma, } \\
\text { - bilgi teknolojilerinin kullanılması içim gerekli becerilere sahip olma, } \\
\text { - teknolojiyi kullanarak bilgi elde etme, }\end{array}$ \\
\hline
\end{tabular}


Mehmet Temizkan

\begin{tabular}{|c|c|}
\hline 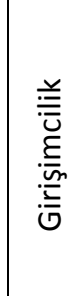 & $\begin{array}{l}\text { - empati kurma, } \\
\text { - insan ilişkilerinde uyumlu davranışlar gösterme, } \\
\text { - plan yapma ve planlarını uygulayabilme, } \\
\text { - risk alma, } \\
\text { - amacına ulaşmak için harekete geçme, }\end{array}$ \\
\hline
\end{tabular}

